\title{
Fission-track evidence for late Oligocene and mid-Miocene activity along the North Anatolian Fault in south-western Thrace
}

\author{
Massimiliano Zattin, ${ }^{1,2}$ Aral I. Okay $^{3}$ and William Cavazza ${ }^{1}$ \\ ${ }^{1}$ Department of Earth and Geoenvironmental Sciences, University of Bologna, Bologna, Italy; ${ }^{2}$ Department of Geology, Palaeontology and \\ Geophysics, University of Padova, Padova, Italy; ${ }^{3}$ Eurasia Institute of Earth Sciences, Istanbul Technical University, Istanbul, Turkey
}

\begin{abstract}
Apatite fission-track (FT) analyses of sandstone samples collected across the trace of the Ganos segment of the North Anatolian Fault (NAF) in south-western Thrace (Turkey) indicate that a significant structural discontinuity was in existence at least by the latest Oligocene. Such discontinuity had a complex kinematic history, as exhumation south of it occurred during the latest Oligocene and north of it during the mid-Miocene. Our
\end{abstract}

data imply that early Pliocene westward propagation of the NAF in the Marmara region followed a pre-existing structural discontinuity; such discontinuity could be related to the development of the Intra-Pontide Suture, marking the terminal closure of the Intra-Pontide Ocean during the Oligocene.

Terra Nova, 17, 95-101, 2005

\section{Introduction}

Large fault zones are major crustal weaknesses which can be repeatedly activated, thus accommodating multiphase and kinematically complex motions - including structural inversionover long time spans. The entire evolution of large fault systems is usually difficult to document because the latest slip along the faults erases most of their earlier history. In this paper, using apatite fission-track (FT) analysis, we document that the Thracian segment of the active North Anatolian Fault (NAF), regarded as a postMiocene structure, has instead a complex, multiphase evolution dating back at least to the late Oligocene.

The NAF is a major dextral transform fault which accommodates the westward motion of the Anatolia plate relative to the Eurasian plate (Fig. 1). East to west, it extends for $1600 \mathrm{~km}$ from the Karliova triple junction to the northern Aegean Sea (Şengör, 1979; Barka, 1992; Westaway, 1994; Hubert-Ferrari et al., 2002). The NAF is thought to have nucleated in eastern Anatolia in the Miocene (10-13 Ma), after closure of the Bitlis suture along the Arabia-Eurasia collision zone (e.g. Şengör et al., 1985; Barka, 1992; Hubert-Ferrari et al., 2002). Westward propagation of the NAF accom-

Correspondence: Dr Massimiliano Zattin, Department of Earth and Geoenvironmental Sciences, University of Bologna, Via Zamboni 67, Bologna 40127, Italy. Tel.: 00 39051 2094579; fax: 0039051 2094522; e-mail: zattin@geomin.unibo.it modated the tectonic extrusion of the Anatolian block away from the collision zone and reached the Marmara Sea-North Aegean region at $5 \mathrm{Ma}$ (Armijo et al., 1999) or $3.4 \mathrm{Ma}$ (Yaltirak et al., 2000). It has been argued (e.g. Jolivet, 2001) that the westward motion of Anatolia could have been facilitated by widespread extension in the Aegean region driven mainly by slab retreat along the Aegean subduction zone.

\section{The NAF in the Marmara region}

The NAF crosses the Marmara Sea and emerges on land south of Ganos Mountain in south-western Thrace (Fig. 1) (Tüysüz et al., 1998; Okay et al., 1999; Yaltırak and Alpar, 2002). Between the Marmara Sea and the Gulf of Saros, the NAF forms a 45-km long linear fault segment, called the Ganos Fault, which crosses the Tertiary sedimentary fill of the southernmost part of the Thrace basin, a large hydrocarbon-bearing basin whose sedimentary fill ranges between the middle Eocene (Lutetian) and the Miocene, reaching a maximum thickness $>9 \mathrm{~km}$ (Turgut et al., 1991; Turgut and Eseller, 2000). Most of the basin fill is middle Eocene to late Oligocene in age, a time span during which the Thrace basin is interpreted to have been in a forearc position between a magmatic arc to the north and a subduction-accretion complex to the south (Görür and Okay, 1996). The latter is composed of an ophiolitic mélange (including blueschist knockers) which is interpreted as now marking the suture of a narrow ocean, the Intra-Pontide Ocean (Şengör and Yilmaz, 1981), which formerly separated the subduction-accretion complex from the Sakarya continental terrane to the south. The Intra-Pontide Ocean is a matter of much debate: (i) according to Görür and Okay (1996) it closed during the Oligocene; (ii) Tüysüz (1999) favours a Cenomanian closure; (iii) Beccaletto (2003) and Stampfli and Borel (2004, Appendix 3) challenge altogether the notion of an Intra-Pontide Ocean in the Marmara region and relate the mélange to the evolution of the eastern Rhodope (Balkanic orogen).

Basinal sediments north of the Ganos Fault are well exposed on Ganos Mountain, a NW-dipping crustal-scale monocline (Okay et al., 2004). The stratigraphy (Fig. 2) begins with the Gaziköy Fm (maximum thickness $855 \mathrm{~m}$; mid-Eocene), an intercalation of siltstone and shale representing distal turbidites (Aksoy, 1987; Yıldız et al., 1997; Şentürk et al., 1998). The Gaziköy Fm is overlain by the Keșan Fm (maximum thickness $3200 \mathrm{~m}$; middle-late Eocene), consisting of interbedded sandstone and shale, a more proximal turbidite facies. This is followed by the Late EoceneEarly Oligocene shales of the Mezardere Fm, $750 \mathrm{~m}$ thick. The Mezardere Formation is in turn overlain by the Oligocene marginal marine-to-fluvial sandstones of the Osmancik Formation, over $500 \mathrm{~m}$ thick. Miocene rocks are characteristically absent just north of the Ganos Fault, whereas they are 


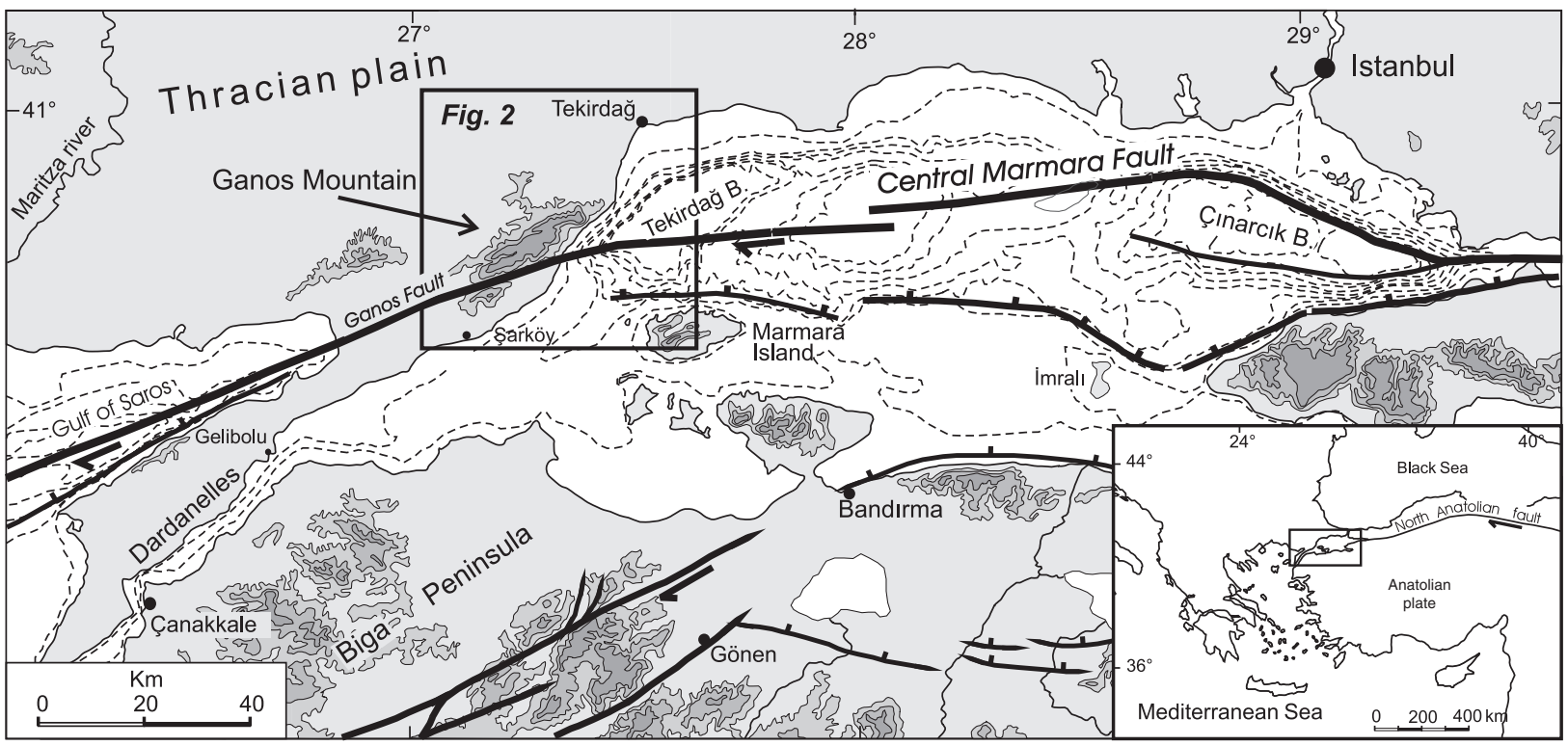

Fig. 1 North Anatolian Fault and other active faults in the Marmara region. The map is compiled from Şaroğlu et al. (1992), Okay et al. (1999, 2000). Faults shown cut Miocene or younger sediments. The bathymetric contours in the Marmara Sea are at 50, 100, then at every $200 \mathrm{~m}$. The topographic contours are at 300, 450 and $600 \mathrm{~m}$.

present in the central portion of the Thrace basin to the NE (Turgut and Eseller, 2000).

The Eocene-Oligocene section south of the Ganos Fault is exposed in the cores of faulted anticlines (Fig. 2). It consists of Eocene distal to proximal turbidites, similar to the Keşan Formation north of the Ganos Fault, unconformably overlain by Miocene sandstone and conglomerate, more than $1000 \mathrm{~m}$ thick, deposited in a fluvial-to-marginal marine setting (Şentürk et al., 1998). The Miocene sequence is truncated by the Ganos Fault. The basal age of the Miocene deposits, constrained by microvertebrate biostratigraphy, is Orleanian (19-16 Ma; late Burdugalian) (Ünay and de Bruijn, 1984; Sümengen et al., 1987).

Eocene sandstone samples were taken north and south of the Ganos Fault (Fig. 2) to date the vertical displacements across it. In addition, several samples were taken on Ganos Mountain in order to constrain the time of uplift and formation of the monocline.

\section{Apatite fission-track analysis and analytical procedures}

Fission-track analysis is based on the spontaneous radioactive fission decay of ${ }^{238} \mathrm{U}$, present in trace amount in several minerals (e.g. Fleischer et al., 1975). FT in apatites all have the same initial length of $c .16 \mu \mathrm{m}$ (Green, 1988) but anneal at rates proportional to temperatures, starting at about $60{ }^{\circ} \mathrm{C}$. Over geological time scales, partial annealing of FT occurs at temperatures between about 60 and $125^{\circ} \mathrm{C}$ (Gleadow et al., 1986; Green et al., 1989). Within this temperature interval [the partial annealing zone (PAZ); Gleadow and Fitzgerald, 1987], tracks shorten in relation to the degree and duration of heating. Therefore, the measurement of FT lengths gives information about thermal evolution in the PAZ temperature range.

Sample preparation and analysis followed the procedures outlined in Zattin et al. (2000). Analysis of apatite FT data provides an apparent age and temperature data. A quantitative evaluation of the thermal history can be carried out through modelling procedures, which find a range of cooling paths compatible with the FT data (Gallagher, 1995; Willett, 1997; Ketcham et al., 2000). The present research, inverse modelling of track length data was performed using the AFTSolve program (Ketcham et al., 2000), which generates the possible T- $t$ paths by a Monte Carlo algorithm. Predicted FT data were calculated according to the Laslett et al. (1987) annealing model.

\section{Analytical results and thermal modelling}

Single grain ages show very low dispersion (chi-squared test passed; Gailbraith, 1981) and are consistently younger than the stratigraphic ages of the samples (Table 1). This implies that the maximum palaeotemperature during burial exceeded the total annealing temperature $\left(c .125^{\circ} \mathrm{C}\right)$, therefore erasing all the pre-existing tracks. Thus the detected apatite FT ages are representative of cooling after

Fig. 2 Geological map and cross-section of the Ganos Mountain and the surrounding region with the localities of the fission track samples and ages (italic) (modified from Okay et al., 2004). Chronolithostratigraphy for the northern and southern sides of the Ganos Fault from Sümengen and Terlemez (1991), Yıldız et al. (1997) and Şentürk et al. (1998). Exact duration of Oligo-Miocene hiatuses north and south of Ganos fault is poorly constrained. 

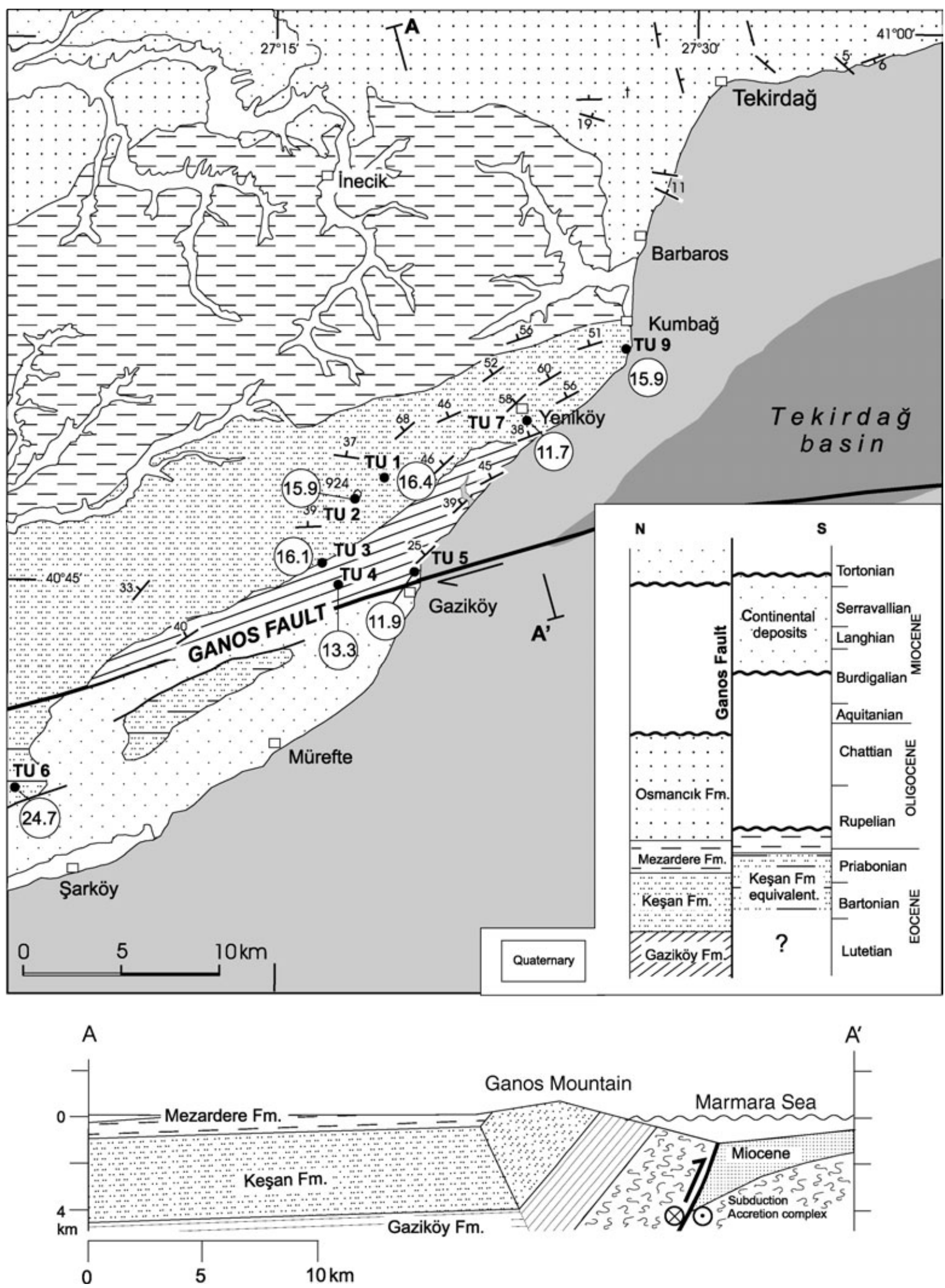
Table 1 Apatite fission-track data

\begin{tabular}{|c|c|c|c|c|c|c|c|c|c|c|c|c|}
\hline \multirow{2}{*}{$\begin{array}{l}\text { Sample } \\
\text { number }\end{array}$} & \multirow{2}{*}{$\begin{array}{l}\text { No. of } \\
\text { crystals }\end{array}$} & \multicolumn{2}{|c|}{ Spontaneous } & \multicolumn{2}{|c|}{ Induced } & \multirow[b]{2}{*}{$P(\chi)^{2}$} & \multicolumn{2}{|c|}{ Dosimeter } & \multirow[b]{2}{*}{ Age $(\mathrm{Ma}) \pm 2 \sigma$} & \multirow{2}{*}{$\begin{array}{l}\text { Mean confined } \\
\text { track length }(\mu \mathrm{m}) \pm S E\end{array}$} & \multirow[b]{2}{*}{ SD } & \multirow{2}{*}{$\begin{array}{l}\text { No. of measured } \\
\text { tracks }\end{array}$} \\
\hline & & $\rho_{\mathrm{s}}$ & $N_{\mathrm{s}}$ & $\rho_{\mathrm{i}}$ & $N_{\mathrm{i}}$ & & $\rho_{\mathrm{d}}$ & $N_{\mathrm{d}}$ & & & & \\
\hline TU1 & 20 & 0.76 & 44 & 1.09 & 634 & 99.0 & 1.28 & 6137 & $16.4 \pm 5.1$ & $13.73 \pm 0.23$ & 1.64 & 53 \\
\hline TU2 & 20 & 1.06 & 91 & 1.57 & 1348 & 89.0 & 1.27 & 6061 & $15.9 \pm 3.4$ & $13.50 \pm 0.30$ & 1.91 & 40 \\
\hline TU3 & 20 & 1.17 & 80 & 1.69 & 1159 & 92.9 & 1.27 & 6022 & $16.1 \pm 3.7$ & $12.93 \pm 0.33$ & 1.99 & 37 \\
\hline TU4 & 20 & 1.45 & 90 & 2.53 & 1565 & 74.2 & 1.26 & 5984 & $13.3 \pm 2.9$ & $14.32 \pm 0.34$ & 1.47 & 19 \\
\hline TU5 & 20 & 2.13 & 104 & 3.86 & 1885 & 42.5 & 1.25 & 5946 & $11.9 \pm 3.2$ & $14.28 \pm 0.17$ & 0.76 & 20 \\
\hline TU6 & 20 & 2.10 & 286 & 1.93 & 2630 & 94.1 & 1.24 & 5908 & $24.7 \pm 3.1$ & $12.60 \pm 0.18$ & 1.49 & 65 \\
\hline TU7 & 20 & 0.67 & 33 & 1.29 & 640 & 99.9 & 1.24 & 5869 & $11.7 \pm 4.2$ & $14.33 \pm 0.29$ & 1.25 & 19 \\
\hline TU9 & 20 & 1.09 & 74 & 1.55 & 1054 & 18.8 & 1.22 & 5793 & $15.9 \pm 4.6$ & $13.53 \pm 0.38$ & 2.03 & 28 \\
\hline
\end{tabular}

Central ages calculated using dosimeter glass CN5 and $\zeta$-CN5 $=369.01 \pm 3.3 . \rho_{\mathrm{s}}$ spontaneous track densities $\left(\times 10^{5} \mathrm{~cm}^{-2}\right)$ measured in internal mineral surfaces; $N_{s}$, total number of spontaneous tracks; $\rho_{\mathrm{i}}$ and $\rho_{\mathrm{d}}$, induced and dosimeter track densities $\left(\times 10^{6} \mathrm{~cm}^{-2}\right)$ on external mica detectors $(g=0.5) ; N_{\mathrm{i}}$ and $N_{\mathrm{d}}$, total numbers of tracks; $P\left(\chi^{2}\right)$, probability of obtaining $\chi^{2}$ value for $v$ degrees of freedom (where $v=$ number of crystals -1 ); a probability $>5 \%$ is indicative of a homogeneous population. Twenty apatite grains were dated for each sample.

the maximum burial and give the time of cooling through the so-called closure isotherm $\left(c .110^{\circ} \mathrm{C}\right)$.

The oldest age $(24.7 \pm 1.6 \mathrm{Ma}$; latest Oligocene) was yielded by sample TU6 (Table 1), collected south of the fault; its track-length distribution $(12.6 \pm 1.5 \mu \mathrm{m})$ suggests a long permanence in the PAZ. All other samples, taken north of the fault, yielded younger ages, ranging from 16.4 to $11.7 \mathrm{Ma}$ (mid-Miocene). In more detail, samples TU1, TU2, TU3 and TU9 have remarkably consistent ages ranging between 16.4 and $15.9 \mathrm{Ma}$. Their track-length distributions are also quite similar, and the mean lengths are shorter than $14 \mu \mathrm{m}$, suggesting a moderate rate of cooling. Samples taken in proximity of the fault and stratigraphically lower within the Ganos monocline (TU4 and TU5) yielded younger ages. Sample TU7 (11.7 Ma) is the only exception to this fairly coherent age distribution. Mean track lengths $>14 \mu \mathrm{m}$ and low standard deviations indicate that samples TU4, TU5 and TU7 underwent rapid cooling.

In order to constrain further the thermal histories of the samples, we applied an inverse modelling procedure to samples where a significant number of tracks have been measured. Given the similarity of data and stratigraphic age and the closeness of the sample locations, samples TU1 and TU2 were modelled together in order to improve the quality of the results. The T-t path thus produced (Fig. 3) shows a moderate rate of cooling through the PAZ, whose lower temperature boundary was reached at $c .10 \mathrm{Ma}$.
Despite the low number of tracks measured, the most recently exhumed samples (TU5, TU7) most likely underwent rather fast cooling through the PAZ at $c .11 \mathrm{Ma}$, as indicated by the lack of short tracks (Table 1).

The first part of the thermal path (between 20 and $12 \mathrm{Ma}$ ) of sample TU3 is very similar to the one obtained for samples TU1 and TU2 (Fig. 3), but from 11 to $5 \mathrm{Ma}$ TU3 was still within the PAZ, in contrast to TU1 and TU2, which during this period were already at temperatures below $60^{\circ} \mathrm{C}$. The best-fit path of sample TU3 seems to indicate the occurrence of a minor heating event between $c .10$ and $7 \mathrm{Ma}$, but the low number of tracks measured and the consequent large envelope area cannot resolve adequately such small thermal events.

The T-t path modelled for sample TU6 - collected south of the Ganos Fault - is markedly different from those of all other samples, with a fast temperature decrease between $c$. 30 and $25 \mathrm{Ma}$ (Fig. 3).

\section{Discussion and conclusions}

Apatite FT analyses along a NE-SWoriented transect across the Ganos segment of the NAF in southern Thrace point to markedly different $T$ $\mathrm{t}$ paths for the rocks north and south of the fault (Table 1; Fig. 3). Exhumation of the southern block across the FT closure isotherm $\left(110^{\circ} \mathrm{C}\right)$ took place in the latest Oligocene, while the northern block was exhumed later (16.4-11.7 Ma; mid-Miocene). Such different FT ages and thermochronological evolutions for samples of similar age and lithology suggest that the present-day Ganos Fault follows the trace of a pre-existing structural discontinuity active by late Oligocene time. (Clearly, FT data across the Ganos Fault must be compared with caution because sample TU6 is located c. $20 \mathrm{~km}$ south-west of TU5. However, the Ganos monocline strikes nearly parallel to the Ganos fault and, therefore, vertical displacement should be very similar all along this segment of the fault.)

Such structural discontinuity had a complex kinematic history, with uplift south of the fault mostly during the late Oligocene and north of the fault during the mid-Miocene. In fact, the FT ages from sample TU6 indicate that by the late Oligocene, the Eocene sediments south of the Ganos Fault were near the surface. This conclusion is supported also by the local stratigraphy, where Miocene marginal marine-to-continental sandstone and conglomerate overlie unconformably the Eocene units (Fig. 2). These lines of evidence imply that during the late Oligocene, deposition came to an end in the southernmost Thrace basin, and was followed by uplift and erosion. In contrast, the Eocene succession north of the fault was still at several kilometres depth by the late Oligocene and was exhumed above the FT closure isotherm $\left(110^{\circ} \mathrm{C}\right)$ only during the middle Miocene, while continental to marginal-marine sandstones were being deposited south of the fault (Fig. 2).

At present, Ganos Mountain forms the steep limb of a crustal-scale, NWdipping monocline, whose hinge is parallel to the Ganos Fault (Fig. 2) 

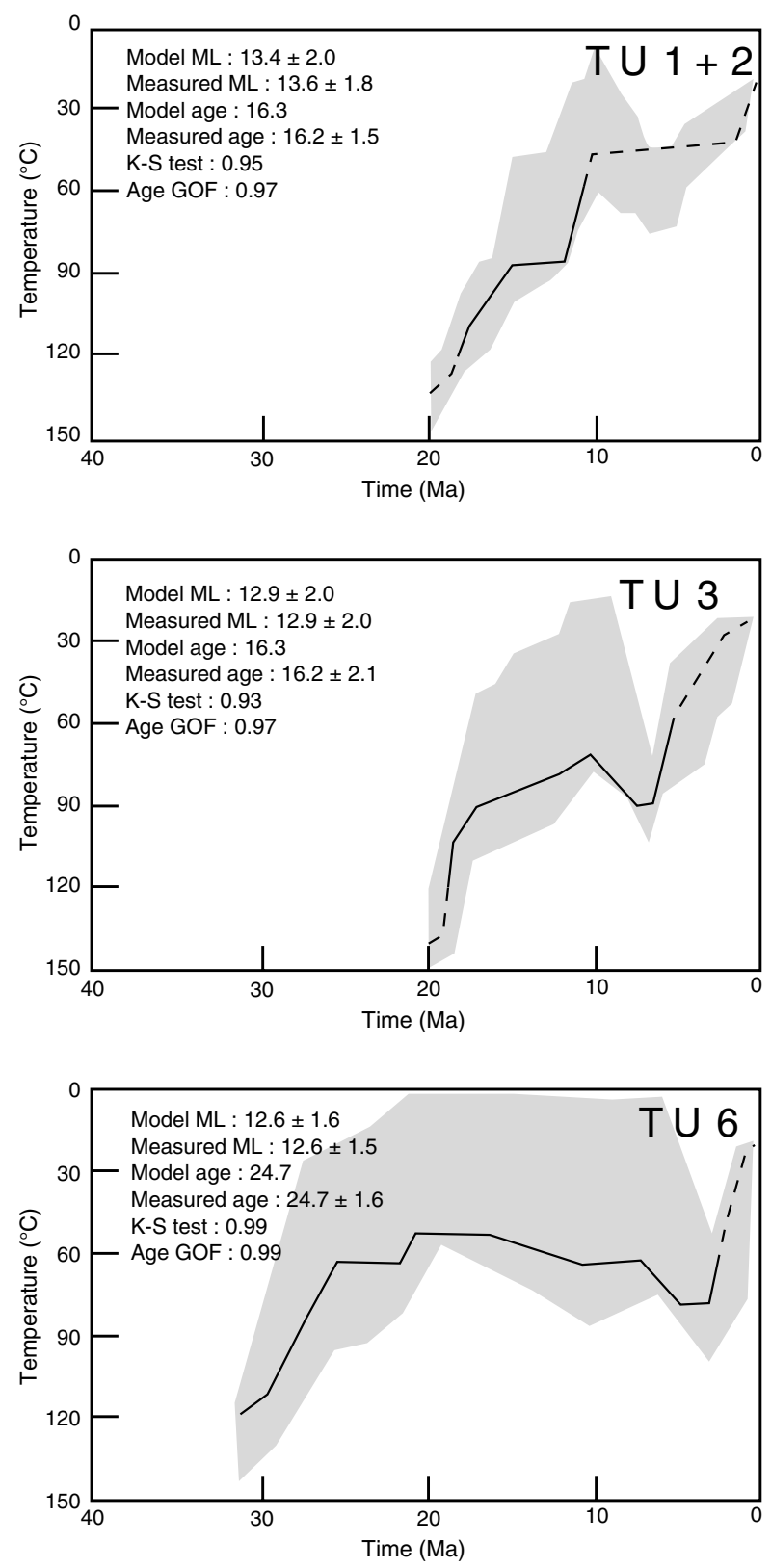

Fig. 3 Time-temperature paths obtained from inverse modelling. Shaded areas mark envelopes of statistically acceptable fit and the thicker lines correspond to the most probable thermal histories. These lines are dashed outside the PAZ as FT data cannot give any information out of this temperature range. On the right, parameters related to inverse modelling are reported: obs. age, observed age (in Ma); pred. age, predicted age (in Ma); obs. MTL, observed mean track length (in $\mu \mathrm{m}$ ); pred. MTL, predicted mean track length (in $\mu \mathrm{m}$ ). K-S test and Age GOF give an indication about the fit between observed and predicted data (values close to 1 are best).

(Okay et al., 2004). The oldest rocks are exposed adjacent to the fault and are represented by sample TU5, collected at sea level. The peak of Ganos Mountain (924 m), where sample TU2 was collected, is located at $c .5 \mathrm{~km}$ orthogonally from the trace of the fault. Samples TU3 and TU4 are located stratigraphically and topographically in-between. Given the regional dip of the beds $\left(c .40^{\circ}\right)$, sample TU2 and TU5 are, therefore, separated by $c .4000 \mathrm{~m}$ of sedimentary succession (see section in Fig. 2).
Assuming a geothermal gradient of $30{ }^{\circ} \mathrm{C} \mathrm{km}^{-1}$, such thickness would translate into a temperature difference of $120^{\circ} \mathrm{C}$ were the sedimentary succession flat-lying during exhumation. The much lower temperature difference between TU2 and TU5 at $c .11-$ $10 \mathrm{Ma}\left(30^{\circ} \mathrm{C}\right.$; Fig. 3$)$ and the faster rate of cooling of TU5 at 11-10 Ma compared with TU1, TU2 and TU3 (Fig. 3) indicate that the Ganos monocline was mostly formed by that time and hence that it cannot be interpreted as a transpressional structure related to Plio-Quaternary tectonic movements along the NAF.

Seismic reflection profiles in the Marmara Sea show that the NAF in the Tekirdag basin dips listrically towards the north-west (Okay et al., 1999; Seeber et al., 2004), thus suggesting that mid-Miocene uplift of the northern block might have occurred above a north-west-dipping contractional or transpressional tectonic lineament (Okay et al., 2004). This reconstruction is supported by the absence of Miocene sediments immediately north of the fault and by their presence immediately south of it. Miocene sediments are again present only away from the Ganos Fault towards the central portion of the Thrace basin, where nevertheless the entire early Miocene and most of the middle Miocene sedimentary section are missing (e.g. Turgut and Eseller, 2000), in agreement with the mid-Miocene exhumation documented by our data to the north of the Ganos Fault.

Apatite FT ages and thermal modelling (Table 1; Fig. 3) indicate that the analysed samples cooled below $60{ }^{\circ} \mathrm{C}$ at the latest by late Miocene time. For example, the T-t path of samples TU1 and TU2 (Fig. 3) show temperatures below $60{ }^{\circ} \mathrm{C}$ already at c. $10 \mathrm{Ma}$ (mid-Miocene), thus pointing to a post-10 Ma maximum cumulative vertical displacement $<1-2 \mathrm{~km}$. South of the NAF sample TU6 had already reached the $60{ }^{\circ} \mathrm{C}$ isotherm by c. $20 \mathrm{Ma}$ (Fig. 3). These data imply that motion along the NAF, which propagated in the study area in the early Pliocene (Armijo et al., 1999; Yaltırak et al., 2000), has not had a significant vertical component.

As mentioned earlier, the development and the very existence of the Intra-Pontide Ocean in the Marmara 
region are much debated. According to Görür and Okay (1996), the terminal closure of the Intra-Pontide Ocean and the coincident development of the Intra-Pontide Suture occurred during the Oligocene. Our data, pointing to a previously unrecognized episode of exhumation of the frontal part of the Thrace forearc basin during latest Oligocene to early Miocene time, can be viewed as supporting such interpretation. Even if we accept the notion that the Intra-Pontide Suture does not extend west of Istanbul into the western Marmara region (see Beccaletto, 2003), the documented exhumation at Ganos Mt could still be the result of far-field stress related to the development of such suture in the westernmost Pontides relatively nearby, where its existence is well documented (see Okay and Tüysüz, 1999, for a review). Finally, early periAegean extensional tectonism (see, for example, Gautier et al., 1999, and Burchfiel et al., 2000) must be also taken into consideration as a viable mechanism for significant and widespread exhumation. Although not conclusive to this end, the data presented in this paper provide new constraints on the thermochronological history of the study area and should be taken into account in future attempts to define the complex tectonic evolution of the Marmara region.

\section{Acknowledgements}

L. Beccaletto and G. Stampfli shared their expertise on the geology of NW Turkey. Helpful comments were provided by I. Dunkl, an anonymous reviewer and the Associate Editor. This research was supported by the Research National Council of Italy (CNR), the Italian Department of Education (M.I.U.R.), Istanbul Technical University Research Fund (project no. 2002), and the Turkish Academy of Sciences.

\section{References}

Aksoy, Z., 1987. Depositional environment of the sequences in the Barbaros-KeşanKadiköy-Gaziköy region (southern Thrace). Proceedings of the 7th Petroleum Congress of Turkey, Ankara, 292-311 (in Turkish).

Armijo, R., Meyer, B., Hubert, A. and Barka, A., 1999. Westward propagation of the North Anatolian fault into the northern Aegean: Timing and kinematics. Geology, 27, 267-270.
Barka, A.A., 1992, The North Anatolian fault Zone. Ann. Tectonicae, 6, 164-195.

Beccaletto, L., 2003, Geology, correlations, and geodynamic evolution of the Biga Peninsula ( $N W$ Turkey). PhD dissertation, University of Lausanne, 140 pp.

Burchfiel, C.B., Nakov, R., Tzankov, T. and Royden, L.H., 2000. Cenozoic extension in Bulgaria and northern Greece: the northern part of the Aegean extensional regime. In: Tectonics and Magmatism in Turkey and the Surrounding Area (E. Bozkurt, J.A. Winchester and J.D. Piper, eds). Geol. Soc. Lond. Spec. Publ., 173, 325-352.

Fleischer, R.L., Price, P.B. and Walker, R.M., 1975. Nuclear Tracks in Solids: Principles and Techniques. University of California Press, Berkeley, CA, 605 pp.

Gailbraith, R.F., 1981. On statistical models for fission tracks counts. Math. Geol., 13, 471-478.

Gallagher, K., 1995. Evolving temperature histories from apatite fission-track data. Earth Planet. Sci. Lett., 136, 421-435.

Gautier, P., Brun, J.-P., Moriceau, R., Sokoutis, D., Martinod, J. and Jolivet, L., 1999. Timing, kinematics and cause of Aegean extension: a scenario based on a comparison with simple analogue experiments. Tectonophysics, 315, 31-72.

Gleadow, A.J.W. and Fitzgerald, P.G., 1987. Uplift history and structure of the Transantarctic Mountains: new evidence from fission track dating of basement apatites in the Dry Valleys area, southern Victoria Land. Earth Planet. Sci. Lett., 82, 1-14.

Gleadow, A.J.W., Duddy, I.R., Green, P.F. and Lovering, J.F., 1986. Confined fission track lengths in apatite: a diagnostic tool for thermal history analysis. Contrib. Mineral. Petrol., 94, 405-415.

Görür, N. and Okay, A.I., 1996. A fore-arc origin for the Thrace Basin, NW Turkey. Geol. Rund., 85, 662-668.

Green, P.F., 1988. The relationship between track shortening and fission track age reduction in apatite: combined influences of inherent instability, annealing anisotropy, length bias and system calibration. Earth Planet. Sci. Lett., 89, 335-352.

Green, P.F., Duddy, I.R., Laslett, G.M., Hegarty, K.A., Gleadow, A.J.W. and Lovering, J.F., 1989. Thermal annealing of fission tracks in apatite: 4. Quantitative modelling techniques and extension to geological timescales. Chem. Geol., 79, $155-182$.

Hubert-Ferrari, A., Armijo, R., King, G., Meyer, B. and Barka, A., 2002. Morphology, displacement, and slip rates along the North Anatolian Fault, Turkey. J. Geophys. Res., 107 (B10), 2235. DOI: $10.1029 / 2001 J B 000393$.
Jolivet, L., 2001. A comparison of geodetic and finite strain pattern in the Aegean, geodynamic implications. Earth Planet. Sci. Lett., 187, 95-104.

Ketcham, R.A., Donelick, R.A. and Donelick, M.B., 2000. AFTSolve: a program for multi-kinetic modeling of apatite fission-track data. Geol. Mater. Res., 1, 1-32.

Laslett, G.M., Green, P.F., Duddy, I.R. and Gleadow, A.J.W., 1987. Thermal annealing of fission tracks in apatite: 2 . A quantitative analysis. Chem. Geol., 65, $1-13$.

Okay, A.I. and Tüysüz, O., 1999. Tethyan sutures of northern Turkey. In: The Mediterranean Basins: Tertiary Extension Within the Alpine Orogen (B. Durand, L. Jolivet, F. Horvàth and M. Seranne, eds). Geol. Soc. Lond. Spec. Publ., 156, 475-515.

Okay, A.I., Demirbağ, E., Kurt, H., Okay, N. and Kuşçu, İ., 1999. An active, deep marine strike-slip basin along the North Anatolian fault in Turkey. Tectonics, 18, 129-148.

Okay, A.I., Kaşlılar-Özcan, A., İmren, C., Boztepe-Güney, A., Demirbağ, E. and Kuş̧̧u, İ., 2000. Active faults and evolving strike slip basins in the Marmara Sea, northwest Turkey: a multi-channel seismic reflection study. Tectonophysics, 321, 189-218.

Okay, A.I., Tüysüz, O. and Kaya, Ş., 2004. From transpression to transtension: Changes in morphology and structure around a bend on the North Anatolian Fault in the Marmara region. Tectonophysics, 391, 259-282.

Seeber, L., Emre, O., Cormier, M., Sorlien, C., McHugh, C. and Polonia, A., 2004. Uplift and subsidence from oblique slip: the Ganos-Marmara bend of the North Anatolian Transform, western Turkey. Tectonophysics, 391, 239-258.

Şengör, A.M.C., 1979. The North Anatolian transform fault: Its age, offset and tectonic significance. J. Geol. Soc. Lond., 136, 269-282.

Şengör, A.M.C. and Yilmaz, Y., 1981. Tethyan evolution of Turkey: a plate tectonic approach. Tectonophysics, $\mathbf{7 5}$, 181-241.

Şengör, A.M.C., Görür, N. and Şaroğlu, F., 1985. Strike-slip faulting and related basin formation in zones of tectonic escape: Turkey as a case study. In: Strikeslip Deformation, Basin Formation, and Sedimentation (K.D. Biddle and N. Christie-Blick, eds)., Soc. Econ. Paleont. Min. Spec. Publ., 17, 227-264. Şentürk, K., Sümengen, M., Terlemez, İ. and Karaköse, C., 1998. Bandırma D-4 Sheet and 10 Page Explanatory Text, 1:100 000 Scale Geological Map Series. General Directorate of Mineral Research and Exploration, Ankara. 
Stampfli, G.M. and Borel, G., 2004. The TRANSMED transects in space and time: constraints on the paleotectonic evolution of the Mediterranean domain. In: The TRANSMED Atlas - The Mediterranean Region from Crust to Mantle (W. Cavazza, F.M. Roure, W. Spakman, G.M. Stampfli and P.A. Ziegler, eds), pp. 53-80. SpringerVerlag, Berlin/Heidelberg.

Sümengen, M. and Terlemez, İ., 1991. Stratigraphy of the Eocene sediments from the southwestern Thrace. Maden Tetkik ve Arama Dergisi, 113, 17-30 (in Turkish).

Sümengen, M., Terlemez, İ., Şentürk, K. and Karaköse, C., 1987. Stratigraphy, Sedimentology and Tectonics of the Gelibolu Peninsula and Southwestern Thrace Basin. Internal Report of the Maden Tetkik ve Arama Enstitüsü, No. 8128, Ankara (in Turkish).

Turgut, S. and Eseller, G., 2000. Sequence stratigraphy, tectonics and depositional history in eastern Thrace Basin, NW Turkey. Mar. Petrol. Geol., 17, 61-100. Turgut, S., Türkaslan, M. and Perinçek, D., 1991. Evolution of the Thrace sedi- mentary basin and its hydrocarbon prospectivity. In: Generation, Accumulation, and Production of Europe's Hydrocarbons (A.M. Spencer, ed.). Spec. Publ. Eur. Ass. Petrol. Geosci., 1, 415-437.

Tüysüz, O., 1999. Geology of the Cretaceous sedimentary basins of the western Pontides. Geol. J., 34, 75-93.

Tüysüz, O., Barka, A. and Yiğitbaş, E., 1998. Geology of the Saros Graben: its implications on the evolution of the North Anatolian Fault in the GanosSaros region, NW Turkey. Tectonophysics, 293, 105-126.

Ünay, E. and de Bruijn, H., 1984, On some rodent assemblages from both sides of the Dardanelles. Turkey. Newslett. Stratigr., 13, 119-132.

Westaway, R., 1994. Present-day kinematics of the Middle East and eastern Mediterranean. J. Geophys. Res., 99, 12071-12090.

Willett, S.D., 1997. Inverse modeling of annealing of fission tracks in apatite: a controlled random search method. Am. J. Sci., 297, 939-969.

Yıldız, A., Toker, V. and Şengüler, İ., 1997, The nannoplankton biostratigraphy of the Middle Eocene-Oligocene units in southern Thrace basin and the surface water temperature variations. Türkiye Petrol Jeologları Derneği Bülteni, 9, 31-44 (in Turkish).

Yaltırak, C. and Alpar, B., 2002. Kinematics and evolution of the northern branch of the North Anatolian Fault (Ganos Fault) between the Sea of Marmara and the Gulf of Saros. Mar. Geol., 190, 352-366.

Yaltırak, C., Sakınç, M. and Oktay, F.Y., 2000, Westward propagation of the North Anatolian fault into the northern Aegean: Timing and kinematics. Geology, 28, 187-188 (Comment).

Zattin, M., Landuzzi, A., Picotti, V. and Zuffa, G.G., 2000. Discriminating between tectonic and sedimentary burial in a foredeep succession, Northern Apennines. J. Geol. Soc. Lond., 157, 629-633.

Received 25 May 2004; revised version accepted 20 October 2004 